\title{
The South Atlantic: AN OVERVIEW OF RESULTS FROM 1983-88 RESEARCH
}

\author{
By Arnold L. Gordon'
}

$A_{\text {curious }}$

feature of the

South Atlantic is

the northward heat

flux across $30^{\circ} \mathrm{S}$
E $\mathrm{ACH}$ of the major ocean basins is unique, but the South Atlantic is unrivaled in its number of singular features. In its polar region are formed intermediate and bottom water masses that cool and lower the salinity of much of the global ocean. The subtropical region has an eastern boundary that doesn't quite extend to the latitude of maximum westerlies, allowing thermocline communication with its counterpart in the South Indian Ocean. Within the Argentine Basin of the South Atlantic one can sample deep water from the North Atlantic, deep and intermediate water from the Pacific, and bottom water formed in the Weddell Sea. These water masses spread and vigorously mix within this cosmopolitan basin and throughout much of the South Atlantic.

Perhaps the most startling attribute of the South Atlantic is the significant equatorward heat flux within the subtropical region. Estimates range from 18 to $86 \times 10^{13} \mathrm{~W}$ for the northward heat flux across the $8^{\circ} \mathrm{S}$ to $32^{\circ} \mathrm{S}$ belt. Associated with this flux is a strong thermohaline circulation, as upper layer water spreads northward to compensate the southward export of colder North Atlantic Deep Water(NADW).

The METEOR expedition of the 1920s and the work during the International Geophysical Year (IGY) of the late 1950s provide a glimpse of the large scale features of the South Atlantic Ocean. In the last five years there has been a surge in our appreciation of the South Atlantic phenomena, mainly beciuse of an Office of Naval Research Accelerated Research Initiative entitled "The Southern Ocean." which was primarily directed toward improvement of the description of the subtropical South Atlantic. The program focused on the poleward "corners" of the subtropical gyre: the separation of the Brazil Current and its confluence with the Malvinas or Falkland Current in the southwest, and the Agulhas Retroflection and Benguela Current in the southeast.

In May 1988, a meeting was organized by Silvia Garzoli to discuss the program accomplishments. Copies of the South Atlantic Accelerated Research

A. L. Gordon, Lamont-Doherfy Gerological Observatory, Pallsades, N.Y logot. 'With contributions frem particlpants in the' ONR-spensored South Alluntic reseurch prosram: S. Bennett. D. Boudra, O. Brown, R.Evans, R. Fine. S. Garzolt, J. Luyten, M. McCartney. D. Olson. G. Roden. T. Whitworth. P. 7emba.
Initiative (SAARI) meeting report are available from Dr. Garzoli at Lamont-Doherty Geological Observatory, Palisades. NY, 10964. What follows is an abbreviated account of the primary results in the SAARI report. Names mentioned here without attributive dates refer to the report, in which additional information and extensive references may be obtained; an abbreviated list of references is included at the end of the article.

\section{Large Scale Circulation}

A curious feature of the South Atlantic is the northward heat flux across $30^{\circ} \mathrm{S}$, a consequence of the global thermohaline circulation cell driven by formation of North Atlantic Deep Water (NADW). In the classical description, southward-moving NADW is replaced by an upper layer return flow derived from Pacific water, with the introduction of Antarctic Intermediate and Subantarctic Mode Water (AAIW/SAMW; the latter term coined by MCCartney). Gordon (1986) suggested that at least some of the return flow is derived from the thermocline water of the Indian Ocean, which has access to the South Atlantic around the southern tip of Africa. The relative influence of the warm and salty Indian water and the colder and fresher Pacific water is crucial to the larger scale climate system, because the Atlantic meridional heat and fresh water fluxes are very sensitive to the ratio of the volume fluxes of the two water types. Gordon suggested that up to $50 \%$ of the required flow could be derived from the Indian Ocean pathway.

The SAARI research does indeed present evidence of Indian Ocean water intrusion into the South Atlantic (Olson and Evans, 1986; Gordon et al., 1987). It is still unknown what part of that inflow eventually contributes tocross equatorial transport in the upper ocean and what part returns to the Indian Ocean along a surface route south of the Agulhas Retroflection. The Agulhas "leakage" into the Atlantic Ocean need not involve thermohaline forcing at all, because purely wind-driven models of the Agulhas Retroflection reveal transfer of Indian Ocean water into the Atlantic (cf. Fig. 3 , p. 16).

The application of inverse methods to data from the International Geophysical Year (IGY) reveals no significant Indian Ocean flow into the Atlantic 


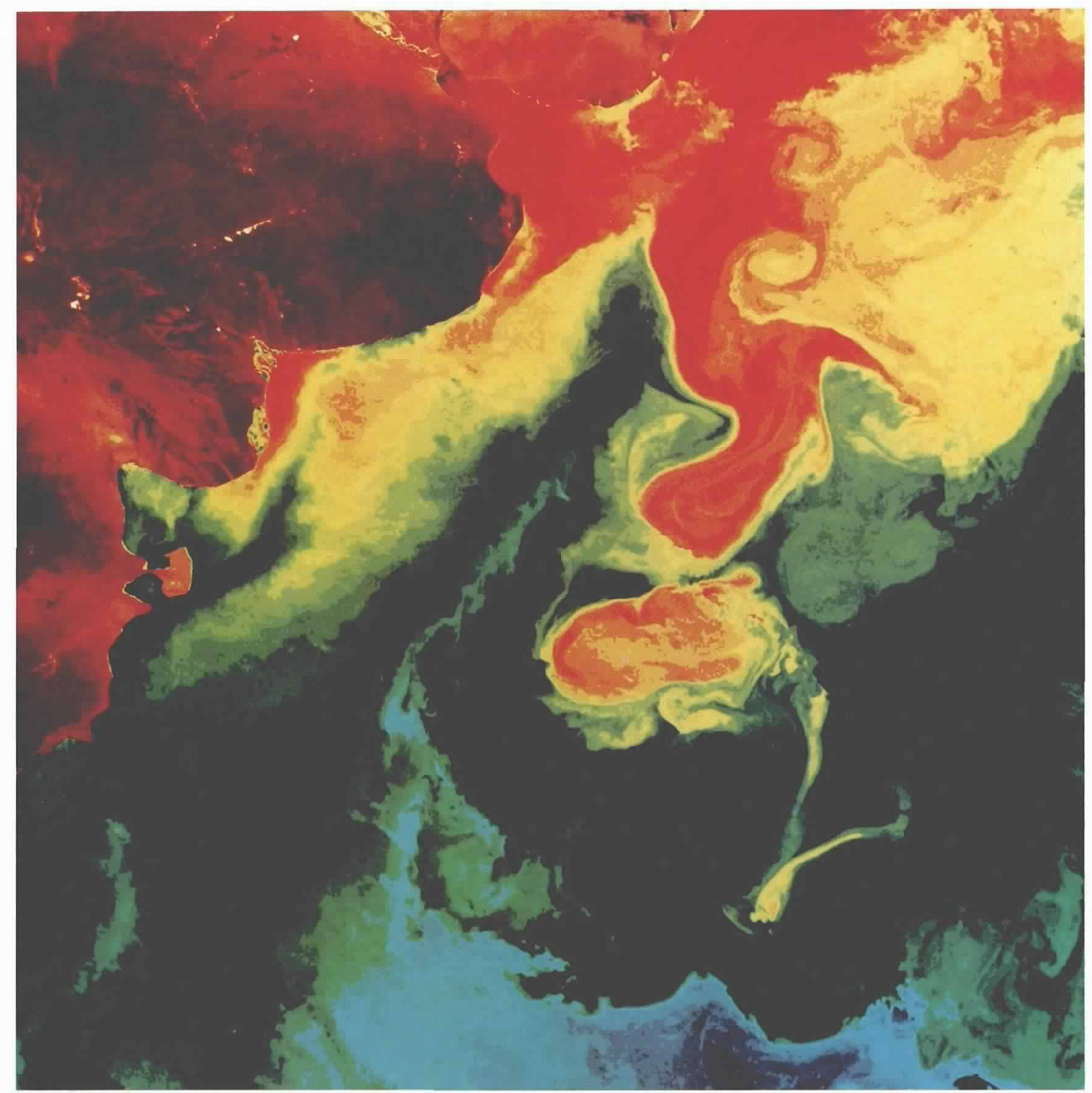

Figure 2: The Brazil Current, the western boundary current associated with the subtropical gyre in the South Atlantic Ocean. flows southward along the continental margin of South America to a point off Argentina and Uruguay where, in the mean, it separates from the coast at about $36^{\circ} \mathrm{S}$. The cold, fiesh subantarctic water in the Malvinas or Falkland Current meets the warm, saline Brazil Current, and both turn eastward into the open

(Rintoul, 1988). Gordon et al. (1987), using 1983 data, found $10 \mathrm{~Sv}$ of Agulhas water entering the Atlantic ( $\left.1 \mathrm{~Sv}=10^{6} \mathrm{~m}^{3} \mathrm{~s}^{-1}\right)$. Whitworth and Nowlin (1987) calculated nearly $20 \mathrm{~Sv}$ of inflow using the 1983/84 Ajax data set, which is subject to eddy aliasing because of a several month hiatus between cruise legs. In her Ph.D. thesis, Bennett evaluated the 1985 CTD data from the Agulhas Retroflection and found that only $2.8 \mathrm{~Sv}$ of water warmer than $9^{\circ} \mathrm{C}$ flowed from the Indian into the Atlantic Ocean; her re-evaluation of the 1983 data set lowered the estimate for that year to $6.3 \mathrm{~Sv}$.

If the Gordon suggestion is correct, it points to a potentially significant climate issue: Might the Atlantic become warmer and saltier during periods when the Agulhas route is favored, versus colder and
Atlantic in a region known as the Brazil-Malvinas Confluence. Warmest surface waters (approx. $25^{\circ} \mathrm{C}$ ) are coded in red. The surface temperature decreases are color-coded through yellow and green; the dark blue shows the coldest water (approx. $9^{\circ} \mathrm{C}$ ). The image was taken at a time when the Brazil Current was in its southward extension and a large anticyclonic (warm) eddy or ring was being formed.

fresher when the Drake Passage route is favored? Might this have important feedback to the production rate of NADW?

The South Atlantic subtropical gyre has an elongated crest stretching across the ocean near $30^{\circ}$ $35^{\circ} \mathrm{S}$. The gyre is marked at its poleward edge by the Antarctic Circumpolar Current. The northern limb of the subtropical gyre consists of a broad sweep towards the northwest. In the northeastern corner of the South Atlantic there is a weak cyclonic (clockwise) gyre, described by Bosley and Gordon. The gyre is formed by the South Equatorial Counter Current and the Angola Current, which flows southward along the African coast. J. Reid clarified this complex pattern by defining the absolute geostrophic circulation of the South Atlantic. 


\section{Contrasting}

water masses are

brought together in

the Argentine Basin

by a layer cake of

boundary currents.
The large scale circulation and the distribution of eddy variability in the near surface layers of the South Atlantic are another focus of research. pursued by Olson. The dynamic height field relative to the $2000 \mathrm{db}$ level and surface velocities from the SAARI and FGGE drifter data sets show that the 2000 db reference level is best for the eastern portion of the basin: however, that reference level clearly is inadequate along the Brazilian coast, where the actual level of no motion probably is higher in the water column (cf. Fig. 1, p. 15). The drifter tracks also reveal the closed anticyclonic flows near the midAtlantic ridge that appear in most descriptions of the South Atlantic circulation.

\section{Brazil-Malvinas Confluence}

Contrasting water masses are brought together in the Argentine Basin by a layer cake of boundary currents: The eddy-rich Brazil-Malvinas (Falkland) Confluence dominates the upper layer, with deeper meridional flow involving NADW. Circumpolar Deep Water and Antarctic Bottom Water. At the meeting, there was not complete agreement as to the exact definition of the Brazil Current, but in general, reference to the Brazil Current is confined to its thermocline expression.

Dropsonde (Pegasus) measurements near $20^{\circ} \mathrm{S}$ confirm the shallowness of the Brazil Current there, with a near-zero flow at $400 \mathrm{~m}$. Evans and Mascarenhas reported Pegasus-referenced geostrophic transport of $17 \mathrm{~Sv}$ for the upper $800 \mathrm{~m}$ at $31^{\circ} \mathrm{S}$. Gordon calculated the geostrophic transport within the upper $800 \mathrm{~m}$ relative to $1500 \mathrm{db}$ to be $20 \mathrm{~Sv}$ at $38^{\circ} \mathrm{S}$. The main growth of the Brazil Current seems to occur between Cabo Frio $\left(24^{\circ} \mathrm{S}\right)$ and $31^{\circ} \mathrm{S}$.

McCartney and Zemba pointed out that the transport of the Brazil Current is sensitive to the choice of reference level. Without the benefit of an array of direct current measurements, they chose a reference level on the basis of water mass properties. With reference levels from $600 \mathrm{~m}$ in the north $\left(27^{\circ} \mathrm{S}\right)$ to $3000 \mathrm{~m}$ in the south $\left(37^{\circ} \mathrm{S}\right)$, they estimated the Brazil Current transport at four sections to be 9 to $76 \mathrm{~Sv}$. increasing from north to south. The southward increase was associated with an increase in dynamic height difference across the current and a tendency for the current to move offshore and develop a deep shear. In the two most northern sections, a northward core of intermediate water was found pressed against the coast.

The Brazil-Malvinas Confluence region was studied in October 1984 (cf. Fig. 2. p. 13). Gordon described the basic thermohaline structure. which featured two large poleward meanders of South Atlantic thermocline water separated by a cold-core cyclonic eddy near $40^{\circ} \mathrm{S}$ and $50^{\circ} \mathrm{W}$. The western meander extended farther south, to $43^{\circ} \mathrm{S}$, with a geostrophic volume transport of $22.5 \mathrm{~Sv}$ relative to $1500 \mathrm{db}$. The eastern meander had a weaker baroclinic structure. though it was associated with warmer surface temperatures. South of the western meander of the Brazil Current were two warm core eddies; the northern one was in the process of separation, whereas the southern one had been separated for at least a month and had been modified by the late winter atmosphere. These modified warm core eddies may not re-coalesce with the main thermocline, and hence they represent a potentially significant salt flux into the subantarctic zone of the South Atlantic.

At depth, the most saline NADW is associated with the western meander of the Brazil Current. The NADW continues flowing south, beneath the Malvinas Current, which indicates that the separation of the deep western boundary current need not be coherent with the shallower thermocline separation latitude: this further complicates the definition of the Brazil Current.

Piola and Gordon presented a detailed picture of the AAIW/SAMW in the Argentine Basin. The $\sigma_{n}$ density interval 27.05 to $27.20 \mathrm{~kg} \mathrm{~m}^{.3}$ in the subantarctic zone of the northern Drake Passage is characterized by two water types with potential temperatures of $3.7^{\circ}$ and $4.8^{\circ} \mathrm{C}$, respectively: both have salinity of approximately $34.2 \mathrm{ppt}$. Thermohaline characteristics are modified by winter sea-air interaction near Burdwood Bank and by mixing with the surrounding waters farther north. Low salinity water derived from the Polar Front is introduced into a denser horizon $\left(27.25 \sigma_{11}\right)$ along the axis of the cyclonic circulation feature described by the Malvinas Current and its return to the south. The salinity at the salinity minimum increases rapidly across the Braril/ Malvinas Confluence, which suggests that the bulk of the subantarctic water advected into the region from the south turns towards the interior. where it spreads under the subtropical thermocline along a broader expanse of the South Atlantic.

Roden (1986) shows that the Brazil Current and Antarctic Circumpolar Current ( $\mathrm{ACC}$ ) do not meet in the central basin to form a common eastward flow as expressed in classical descriptions. Instead, the two currents diverge near $42^{\circ} \mathrm{W}$. where the former returns to subtropical latitudes and the latter continues eastward. The Brazil current extension typically displays three meanders between the coast and $40^{\circ} \mathrm{W}$. with a wavelength of about $400 \mathrm{~km}$ and an amplitude of about $200 \mathrm{~km}$.

Olson presented a hypothesis for the wavelike structure of the confluence region: the stationary wave train acts as an energy reservoir into which the Brazil/Malvinas currents slowly impart energy. This energy is then periodically released back into the boundary as the wave train becomes transient. Theoretically, this can occur if the large scale eastward flow is reduced in amplitude. The drifter momentum fields and the satellite imagery suggests that such an event occurred in January-February 1985. During this time, drifters reentered the boundary from the offshore recirculation and the amplitude of the offshore waves in the satellite imagery was reduced. As the event continued, drifters along the coast accelerated from speeds of order $0.30 \mathrm{~m} \mathrm{~s}^{-1}$ to speeds greater than $1 \mathrm{~m} \mathrm{~s}^{-1}$. This mechanism for storing and periodi- 


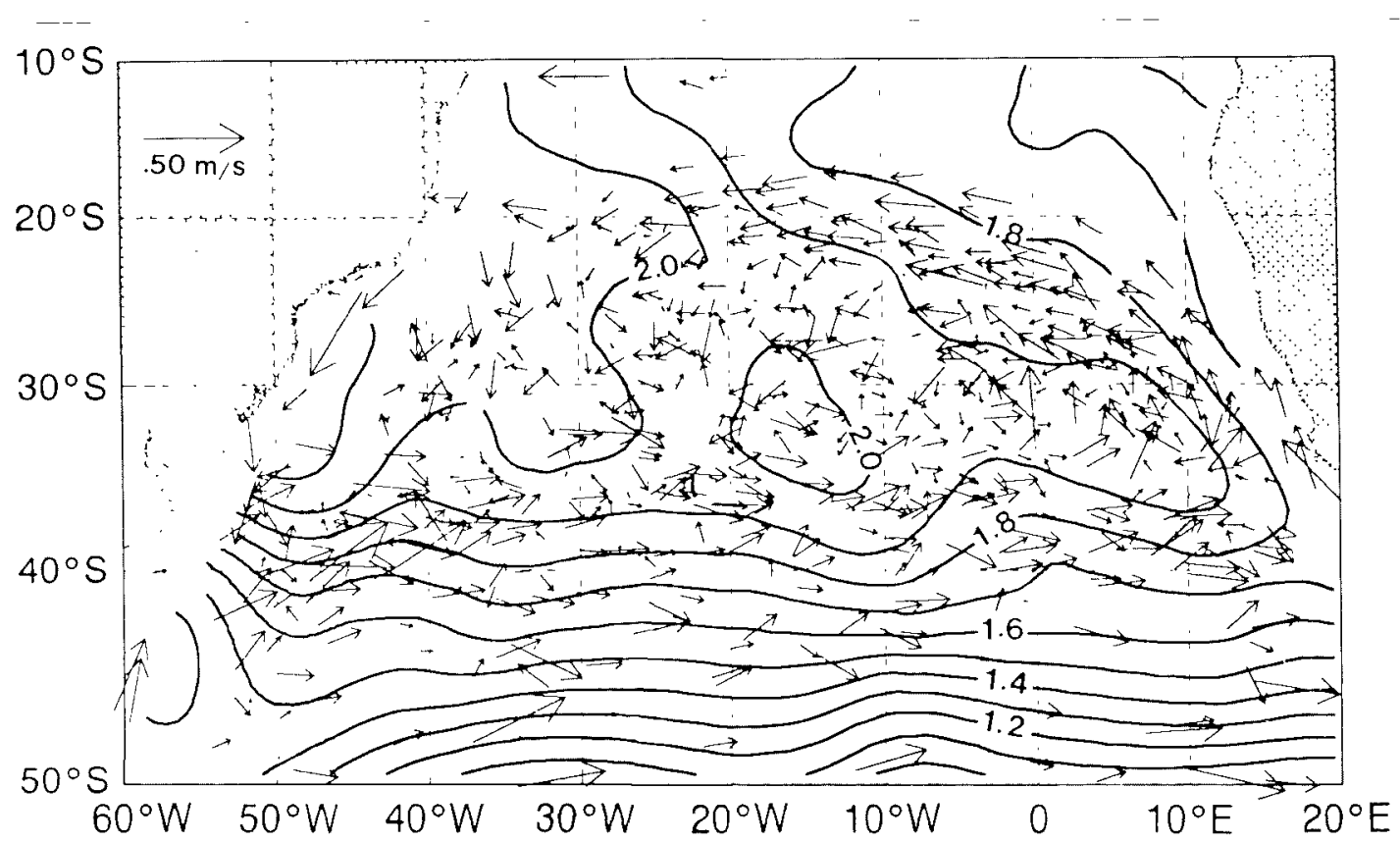

Figure 1: Surfuce drifter-derived leberthes are shown superimposed on the dramic topography $(d y n m)$ of the sea sarface relative to 2000 dhat , frem the Lavitus data. Drifters incladed are those of the First Global GaRP Experiment $F G G E$ ) and the ONR Southern Ocan Studies. The drifter lederities in the figure are means cres a wo weeh period. whach exe'eds the longest Lagranglan tme scales computed from the differ records $T_{0}$

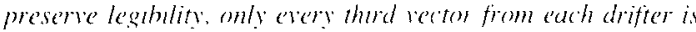

cally releasing energy is probably responsible for the highly energetic rings, despite the fact that the Brazil Current is a weak boundary current, compared to the Gulf Stream.

Roden finds that the Brazil current and its associated eddies have deep, vertically coherent signatures that are recognizable to $3000 \mathrm{~m}$. in common with other western boundary currents. Strong thermohaline fronts accompany the boundaries of the Brazil current and the ACC. Hydrostatic stabilities in these frontal zones are low, favoring seasonal convection and formation of mode waters. Density-compensated temperature and salinity fronts occur not only in the upper layers of the subantarctic frontal zone. but also at abyssal depths below $3500 \mathrm{~m}$.

Three inverted echo sounders (IES) were deployed for 18 months in the confluence region by Garzoli, in order to develop a time series of the complex and highly variable baroclinic field (Garzoli and Bianchi, 1987). Since dynamic height is linearly proportional to the travel time measured by the IES array, time series of geostrophic baroclinic flow can be successfully traced relative to the initial condition set by CTD data. Garzoli found the mean surface geostrophic velocity associated with the Brazil Current to be $35 \mathrm{~cm} \mathrm{~s}^{-1}$ corresponding to a geostrophic transport of $11 \mathrm{~Sv}$ for the upper $800 \mathrm{~m}$, relative to $800 \mathrm{db}$. During the monitored period, the $0 / 800 \mathrm{db}$ geostrophic velocity reached a maximum value of 55 $\mathrm{cm} \mathrm{s}^{-1}$ in September-October 1985. corresponding to a transport of $18 \mathrm{~Sv}$ relative to $800 \mathrm{db}$. The latter shown. The aserement between drifter trajeetorics and the bare-

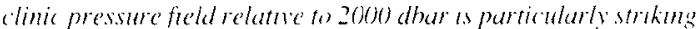

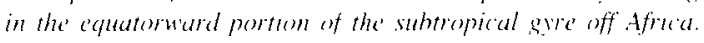
None of the drafters escape the subtropical gre. Closer allalysis of the drifter data set shom's the drift to be aross the drmamic

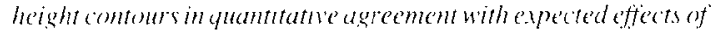
the Ekman laver on the surface velocity

occurred when the Malvinas Current had penetrated farther north; the increase could have resulted from a composite of the Brazil Current and Malvinas Current transport. The analysis of the IES records (supported by the infrared images studied by Olson and others) indicates that the confluence exhibits a low frequency east-to-west displacement. with an amplitude of about $100 \mathrm{~km}$. It appears to be related to the maximum northward penetration of the Malvinas Current, which raises several questions: Does the Malvinas Current extend farther north because a weaker Brazil Current separates at a lower latitude? Or does a stronger Malvinas Current forced by stronger winds farther south induce a more northerly separation of the Brazil Current?

In April 1987, the first Abyssal Boundary Current Studies field program concluded with the recovery of a 14-mooring current meter array from the southern Argentine Basin. The program was designed to sample current, temperature and conductivity between $1000 \mathrm{~m}$ and the bottom. to study the spreading paths and volume transport of cold Weddell Sea Deep Water entering the South Atlantic. Whitworth presented preliminary results from this experiment, which was sponsored by the National Science Foundation, with supplementary analysis support from ONR. The westward boundary current on the northern flank of the Falkland Plateau varied between 50 and $100 \mathrm{~km}$ in width and was bounded on the north by an eastward abyssal recirculation. Current strength in both regimes frequently reached $50 \mathrm{~cm} \mathrm{~s}^{-1}$ at depths of 5000
Current

strength in both

regimes frequently reached $50 \mathrm{~cm} \mathrm{~s}^{-1}$ at depths of 5000 to $6000 \mathrm{~m}$. 
to $6000 \mathrm{~m}$. The coldest water sampled in the Argentine Basin had a potential temperature of $-0.4^{\circ} \mathrm{C}$, almost $0.2^{\circ} \mathrm{C}$ colder than recorded in the historical hydrographic data base for the South Atlantic. Preliminary analysis of the data suggest that the influx of Weddell sea water is influenced by the location and strength of the ACC and the clockwise abyssal circulation of the Argentine Basin.

\section{Agulhas Retroflection and Benguela Current}

The Agulhas Current carries warm, salty thermocline water poleward in the Indian Ocean. However, the current effectively leaves behind its western boundary where the African continent terminates near $35^{\circ} \mathrm{S}$. The Agulhas rounds the tip of Africa and turns toward the South Atlantic, but before entering the open Atlantic it curls back toward the Indian Ocean, forming the Agulhas Retroflection. However, not all of the Agulhas water participates in the retroflection. Hydrographic, infrared and satellite-tracked drifter observations indicate that as much as $15 \%$ of the Agulhas water continues into the South Atlantic. The presence of separated rings, however, makes it difficult to partition the transport between time dependent and mean circulation.

Gordon et al. (1987) described the Agulhas Retroflection as observed in late 1983. The main retroflection was near $21^{\circ} \mathrm{E}$, with two large warmcore Agulhas rings to its west. The transport into the main retroflection through the Agulhas Passage was $70 \mathrm{~Sv}$ relative to $1500 \mathrm{db}$ ( $95 \mathrm{~Sv}$ relative to the sea floor). Most of the transport entered the retroflection and returned to the Indian Ocean, but $10 \mathrm{~Sv}$ (relative to $1500 \mathrm{db}$ ) continued into the South Atlantic within the region between the two eddies and the African mainland. The ring immediately to the west carried $40 \mathrm{~Sv}$ relative to the $1500 \mathrm{db}$ level; its core properties were identical to the water enclosed by the retroflection. These characteristics suggest that the retroflection eddy was formed just prior to the field work. The second eddy, which was centered about $250 \mathrm{~km}$ southwest of Cape Town, carried $35 \mathrm{~Sv}$ relative to $1500 \mathrm{db}$. It encircled a core of Agulhas water that had been highly altered by the action of the winter atmosphere.

Olson and Evans (1986) reported that the two Agulhas rings moved westward into the South Atlantic after formation. Their trajectories suggest that the rings, some of the most energetic in the world ocean, interact with the bottom topography. The energy flux into the South Atlantic for each eddy amounts to about $7 \%$ of the annual wind energy input over the entire South Atlantic. Their large horizontal scales, however, make the rings more linear than rings associated with the Gulf Stream. The rates of ring translation are significantly higher than expected from theoretical computations of self-induced motion, so the rings also must be steered by the mean currents.

Olson reported on the results of drifter launches during the 1983 and 1985 Agulhas cruises. These drifters, along with eight FGGE drifters that entered this area and one SAARI drifter from the Brazil/

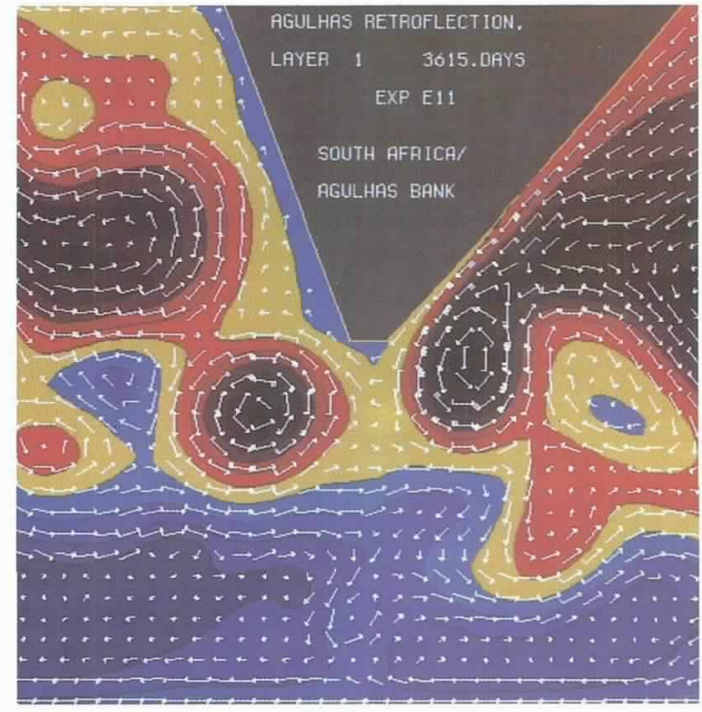

Figure 3: A "snapshot" visualization from a three-layer numerical model simulation of the Agulhas Current Retroflection region off South Africa (Boudra and Chassignet. 1988). Rings of warm Agulhas water from the southwest Indian Ocean water form near the tip of Africa and drift northwestward into the subtropical South Atlantic; however, the largest part of the Current 'retroflects,' turning back into the subtropical South Indian Ocean. A full-length arrow represents an upper level current velocity of $0.25 \mathrm{~m} \mathrm{~s}^{-1}$. and each barb on an arrow adds a $0.25 \mathrm{~m}$ $\mathrm{s}^{-1}$ velocity increment; the maximum speeds shown are about $1 \mathrm{~m}$ $s^{-1}$ in the ring forming near the tip of Africa. Colors represent the depth of the first model interface. The shallowest depths (darkest blue) are less than $100 \mathrm{~m}$, and the deepest depths (darkest red) are greater than $550 \mathrm{~m}$; the colors change at depth intervals of $50 \mathrm{~m}$.

Malvinas extension, all trace out a uniform arc, which corresponds to a frontal system that separates South Atlantic subtropical gyre waters from waters emanating from the Benguela upwelling region.

Gordon and Haxby discussed a sequence of Geosat data from November 1986 to September 1987, which disclosed numerous transient sea level highs within the South Atlantic subtropical gyre in the latitude range of $25-30^{\circ} \mathrm{S}$. The highs migrated from the Agulhas Retroflection and drifted northwestward at 5 to $7 \mathrm{~cm} \mathrm{~s}^{-1}$. The 1987 population of eddies in the South Atlantic and their mean drift velocity suggest a production rate of 3 to 4 per year. One of the larger eddy features revealed by Geosat was crossed by $\mathrm{R} / \mathrm{V}$ Discovery during a CTD survey of the Benguela Current in May 1987. The dynamic height of the sea surface relative to $3000 \mathrm{db}$ revealed a $30 \mathrm{dyn} \mathrm{cm}$ crest near $8^{\circ} \mathrm{E}$, in excellent agreement with the Geosat data. The CTD data revealed a distinct sign of Indian Ocean stratification in the upper segment of the thermocline within the eddy: an isohaline layer in the $15-18^{\circ} \mathrm{C}$ interval. There is some evidence for surface modification caused by enhanced evaporation from the warm eddy into the colder atmosphere above it. Such a process could eventually remove the Indian Ocean signature of the eddy.

Luyten deployed a two-year array of 10 moorings designed to explore the eddy field and mean flow of the Agulhas Retroflection region. Each mooring had current meters at nominal depths of 200, 750, 1500 
and $4000 \mathrm{~m}$. Several moorings were deployed in the Agulhas Current and showed velocities of $80-100 \mathrm{~cm}$ $\mathrm{s}^{-1}$. The moorings deployed in the retroflection region showed very strong and variable flow extending to $4000 \mathrm{~m}$. The eddy kinetic energy at $4000 \mathrm{~m}$ was 165 $\mathrm{cm}^{2} \mathrm{~s}^{-2}$, comparable in amplitude to the Gulf Stream recirculation. Most of this variability occurred with periods between 80 and 120 days, and there was significant variability at the longest periods of 2 years. The mean flow, defined as a record-length average. revealed a large scale flow pattern consistent with the presence of a smeared-out, meandering Agulhas Current. The moorings west of the retroflection showed northwestward flow at all depths, which suggests a net flow from the South Indian into the South Atlantic basin. The transport between the westernmost moorings along $37^{\circ} \mathrm{S}$ and between 200 and $4000 \mathrm{~m}$ depths was approximately $20 \mathrm{~Sv}$.

The Agulhas Current introduces several Indian Ocean water types into the Agulhas Retroflection region, all at densities less than $\sigma_{0}=27.7 \mathrm{~kg} \mathrm{~m}^{-3}$ (shallower than 1500 meters). Within the Agulhas Retroflection, Indian Ocean water masses are modified in two ways: 1. the upper thermocline water, upon exposure to the colder atmosphere, forms water that is anomalously salty relative to the Agulhas inflow: 2. the deeper thermocline water mixes with South Atlantic water. The "contamination" of the Agulhas Retroflection thermocline with South Atlantic water increases with depth, until density 27.7 $\mathrm{kg} \mathrm{m}^{-3}$ is reached, below which the water is almost totally from the South Atlantic.

Chlorofluoromethane (CFM) data collected as part of the 1983 Agulhas Retroflection cruise were used by Fine et al. (1988) to investigate the modification of water masses in the Agulhas Retroflection region. South Atlantic waters are generally higher in CFM concentration and consequently more recently ventilated (by at least two years) than the waters of the South Indian Ocean. A probable explanation is that the Indian Ocean water is farther downstream from the more convectively active South Atlantic subantarctic sector. In the temperature range of $14^{\circ}$ to $4^{\circ} \mathrm{C}$, there are substantially greater amounts of more highly ventilated South Atlantic water in the Agulhas return flow to the Indian Ocean. which points to the importance of the retroflection region in ventilating the thermocline and intermediate waters of the South Indian Ocean.

Olson. Fine and Gordon examined the winter modification of upper thermocline waters in the Agulhas Retroflection region. Consideration of the CFM concentration of the convected layers found in Agulhas rings observed in the 1983 data suggest that the convective changes in the surface layers are highly episodic, which can be demonstrated using the relative CFM concentrations in a simple mixed layer model. Model calculations of the CFM fluxes constrain the actual time for convection in Agulhas ring cores to a total period of one to two months. Mode waters warmer than $15.5^{\circ} \mathrm{C}$ are found exten- sively in the Ajax data along the prime meridian. Thus, wintertime modification of upper thermocline waters in Agulhas eddies could be considered a possible source for Subtropical Mode Water of the South Atlantic Ocean.

Single-and multiple-layer experiments performed with a primitive-equation numerical model in quasiisopycnic coordinates (Boudra and deRuijter, 1986; Boudra and Chassignet, 1988) have shown that the Agulhas Current separates from the tip of Africa, provided the no-slip condition is specified on that boundary (Fig. 3). The strength of the model retroflection may then be viewed in the context of the resulting changes in the Agulhas' vorticity balance. Along the coast, the gain in positive vorticity induced by decreasing planetary vorticity is balanced largely by diffusion into the no-slip boundary. After separation. potential vorticity is essentially conserved, and in a one-layer case, the further decrease of planetary vorticity induces turning back toward the Indian Ocean. With more than one layer, the "stretching" vorticity term complements the planetary vorticity advection term. The stretching becomes increasingly important as the contrast between mean upper ocean potential vorticity in the southwestern Indian and the southeastern Atlantic Oceans increases. Fluid parcels attempting to leave the retroflection toward the west are imparted a torque through the stretching term, which turns them back toward the Indian Ocean. Large upstream transport favors large values of planetary vorticity advection and stretching and thus a strong retroflection.

\section{Conclusion}

The ONR-sponsored research on the circulation of the South Atlantic has revealed a more quantitative picture of and additional insight into many of the special features of that ocean. The research has exposed new features as well, and has stimulated interest for continued study. Some ongoing work is the tracer chemistry South Atlantic Ventilation Experiment, which will provide more specific information on origin and time scales of the various water mass that influence the property fields and fluxes of the South Atlantic. As part of the World Ocean Circulation Experiment, the South Atlantic Ocean will be the subject of numerous observational and modeling programs during the $1990^{\circ}$ s.

\section{References}

Boudra, D.B. and W.P.M. de Ruijter. 1986: The wind-driven circulation of the South Atlantic-Indian Ocean. II; Experiments using a multi-layer numerical model. Dép-Séa Res. 33. 447-482.

Boudra. D. B. and E. P. Chassignet. 1988: The dynamics of Agulhas Retroflection and Ring Formation in a Numerical Model. I: The Vorticity Balance. I Phys. Oceanogr.. 18, 280-303.

Fine. R.. M.J. Warner and R.F. Weiss. 1988: Water mass modification at the Agulhas Retroflection: Chlorofluoromethane Studies, Decp-Sea Res. 35(3): 311-332.

Garcoli, S. and A. Bianchi, 1987: Time-Space Variability of the Local Dynamics of the Malvinas/Brazil confluence as

[ PLEASE TURN TO PAGE 58 ] 
great success during the forty-five years since the school's founding. The resources available to students in the form of facilities, curriculum and faculty are extensive. The RSMAS library is accessible to students 24 hours a day, 365 days a year. Each student receives nearly unlimited time on the school's computing system, which includes links to a variety of academic and research networks. And, of course, individual divisions provide facilities equipped to satisfy research needs within their respective sub-disciplines. The small student-tofaculty ratio ( $\sim 2$ ) enables students to work closely with their advisors and to play an active role in research. These factors and more come together at the RSMAS to create an exceptional educational environment.

Despite the excellent provisions of the RSMAS, students have gone a step further and established two organizations to address student needs and concerns. These are the Marine Science Graduate Student Organization (MSGSO) and the Organization of Tropical Marine Science Students (OTMSS). Soon after the founding of the RSMAS, the MSGSO was established to insure student representation within the University. It has remained an active voice throughout the school's history. A representative of the MSGSO occupies a voting position on the school's Academic Committee and participates in the formulation of policy regarding students. The MSGSO also provides a number of services such as short-term, no-interest loans and new student orientation intended to help with the problems of "student life." As a means of promoting student-faculty exchange as well as student-student interaction, the MSGSO operates a commons complete with music and a full bar. Finally, the MSGSO has created a travel fund program to provide financial assistance to students presenting the results of their research at scientific meetings.

Monies allotted to this fund annually are matched by the Office of the Dean. Excluding the Dean 's matching funds, the MSGSO receives no monetary support from the University, and all of its annual budget is met through fund-raising activities. Chief among these is the Annual MSGSO Student Auction, an event in which businesses and individuals donate their services and merchandise. The donations are auctioned with earnings going to the MSGSO. Last year the event raised nearly $\$ 8,000$.

The Organization of Tropical Marine Science Students was established in 1986 to promote activities which contribute di- rectly to the education and training of marine science students.

The OTMSS sponsors a number of field trips to various environments in South Florida and the Caribbean, stressing the importance of an interdisciplinary approach in the marine sciences. Through these organized trips, students gain direct exposure to. and an increased appreciation of, the sub-disciplines of their fellow students. Field trip leaders are faculty members or students with specialties in the areas to be visited. Beginning this fall, the OTMSS will sponsor a series of work shops directed at improving students' presentation skills.

\section{The South ATLANTIC [CONTINUED FROM PAGE 17]}

Revealed by Inverted Echo sounders.I.Geophss Rer. 92. (C2). 1914-1922.

Gordon. A. L. 1986: Inter-Ocean Exchange of Thermocline Water. I Gerphys. Res.. 9/(C+): 5037.5046.

Gordon. A. L.. J. R. E. Lutjeharms and M. L. Gründlingh 1987: Stratification and Circulation at the Agulhas Retroflection. De'ep-Sed Res $341+1.56 .5-590$

Olson. D. B. and R. H. Evans, 1986: Rings of the Agulhas Current. De'p) Se'd Re's, 33, 27-42.

Ou. H.W. and W. de Ruyter, 1986: Separation of an

\section{Satellite Altimetry [CONTINUED FROMI PAGE I1]}

\section{References}

Bemstein. R.L.. G.H. Born and R.H. Whritner, 198 ? Seasat altimeter determination of ocean current varability. I Gesphys. Re's. 87. 3261-3268.

Born, G.H. M.A. Richards and G.W. Rosborough. 1982: An empirical determmation of the effect of sea-state bias on the SEASAT altimeter. $J$ Geopless. Re's. 87. 3221-3226.

Chelton, D.B. 1988: WOCE/NASA Altmeter Algorithm Workshop. U.S. WOCE Tech. Rep. No. 2. U.S. Planning Office for WOCE, College Station. TX.. 70 pp.

Cheney, R.E., J.G. Marsh and B.D. Beckley, 1983: Global menoscale varability from collinear tracks of Seasat altimeter data. J. Goophys Res, 88. $4.343+4.354$

Cheney. R.E., and L. Miller. 1988: Mapping the 1986-1987 El Viño with Geosat altimeter dati. Eos Trams. Amler. Gerophys. Union. 69, 754-755.

Douglas. B.C.. R.E. Cheney and R.W. Agreen. 1983: Eddy energy of the Northwest Allantic and Gulf of Mexico determmed from Geos-3 altimetry. I Gaphos Res, Rig. 4595-9603

Douglus. B.C.. D.C. MCAdoo and R.E. Cheney. 1987: Oceanographic and geophysical applications of atellite altimetry. Rov. G(ophlys. 25. $875-880$

Fu. L.-L.. 1983: Recent progress in the application of satellite altmetry to observing the mesoscale variability and general circulation of the oceans. Rer. Geophys. Space Phys. 21, 1657-1666.

Fu. L.-L...J. Vasquez and M.E. Parke. 1987: Seasonal variability of the Gulf Stream from satellite at-
The importance of effective communication is fully recognized among students at the RSMAS, and the planned workshops will combine expert instruction with practical experience. Individual workshops will cover written and verbal skills, and will be lead by selected faculty members noted for their presentation skills.

The above are just a few of the ways that graduate students at the University of Miami's Rosenstiel School of Marine and Atmospheric Science are enriching the educational experience for themselves and their fellow students. We encourage other students to share their successes.

inertial boundary current from an irregular coastline. J. Phy. Ocedmogr.. 10. 280-289

Rintoul. S.. 1988: Mass, heat and nutrient fluxes in the Atlantic Ocean determined by inverse methods. Ph.D. thesis, Massachusetts Institute of Technology/Woods Hole Oceanographic Institute Joint Program, 287 pp.

Roden. G., 1986: Thermohaline fronts and baroclinic flow in the Argentine Basin during the austral spring of $1984 . I$ Goophys. Re's., 91. 5075 5093.

Whitworth. T. and W. Nowlin, 1987: Water masses and currents of the Southern Ocean at the Greenwich meridian. I. Geophys Res..92,6462$6+76$.

timetry. I. Geophys. Res. 92, 749-754.

Fu. L.-L.. and D.B. Chelton, 1985: Observing largescale temporal variability of ocean currents by satellite altimetry: with application to the Antarctic Circumpolar Current. $J$. Geophys. Res., 9(). $4721-4739$.

Marsh, J.G.. (and 19 other authorst. 1988: A new gravitational model for the earth from satellite tracking data: GEM-T1. I. Gerphys Re's.. 93. $6169-6215$.

Mazzega. P. 1985: M2 model of the global ocean tide derived from SEASAT altimetry. Mar. Good., $y$ $335-36.3$.

Parke. M.E.. R.H. Stewart. D.I. Farless and D.E. Cartwright. 1987: On the choice of orbits for at altimetric satellite to study ocean circulation and tides. J. Geophys. Re's. 92, 11.693-11.707.

Tai. C.-K., and C. Wunsch, 1984: An estimate of global absolute dynamic topography. J. Phy Oceanogr.. 14.457-463.

Tapley. B.D., G.H. Born, and M.E. Parke. $1982 \mathrm{a}$ : The SEASAT altimeter data and its accuracy assessment. J. Geoplyss. Res.. 87. 3179-3188.

Tapley, B.D., J.B. Lundberg and G.H. Bom. 1982b: The SEASAT altimeter wet tropospheric range correction. I. Geuphes. Re's., 87. 3213-3220.

Topex Science Working Group. 1981: Satellite altimetric measurement of the ocean. Doc. 400 111. Jet Propul. Lab., Pasadena, Calif.

Woodworth. P.L., and D.E. Cartwright. 1986: Extraction of the M2 ocean tide from SEASAT altimeter data. Gerphis I Rut Asto. Sex. Bt. $227-255$.

Yunch. T.P. S.C. Wu and S.M. Lichten, 1985: A GPS measurement system for precise satellite tracking and geodesy. I. Astronaut. Sol... 33 $367-380$. 